\title{
Religion, weight perception, and weight control behavior
}

\author{
Karen Hye-cheon Kim * \\ Cornell University, Division of Nutritional Sciences, 351A Martha Van Hall, Ithaca NY 14853, USA
}

Received 27 September 2005; received in revised form 17 February 2006; accepted 14 March 2006

\begin{abstract}
Religion's relationships with weight perception and weight control behavior were examined using data (3032 adults aged 25-74) from the National Survey of Midlife Development in the United States. Religion was conceptualized as denomination, religious attendance/practice, religious social support, religious commitment, religious application, and religious identity. Weight perception was conceptualized as underestimating body weight, overestimating body weight, and accurately assessing body weight. Respondents also reported whether they had engaged in any intentional weight loss (yes/no) in the last 12 months. Logistic regression was used, with significant results being set at a $p$-values of $<.01$ and $<.05$. Accurately assessing body weight was the reference category for all weight perception analyses. Women with greater religious commitment and men with greater religious application had greater odds of underestimating their body weight. This relationship remained significant, controlling for age, race/ethnicity, education, and income. Jewish women had greater odds of overestimating their body weight. There were no relationships between religion and weight control behavior. Relationships between religion, weight perception, and weight control behavior illustrate religion's multidimensionality.
\end{abstract}

(C) 2006 Elsevier Ltd. All rights reserved.

Keywords: Religion; Weight perception; Weight control behavior; Eating disorders; Body image; Dieting

\section{Introduction}

Body weight, whether it involves too much or too little, has become a topic of public health significance. Despite national efforts to fight the obesity epidemic, obesity continues to be a persistent public health problem (Flegal, Carroll, Ogden, \& Johnson, 2002; Mokdad et al., 2003). Underweight and an excessive concern with thinness are also severe and prevalent problems with broad public health ramifications (Newman et al., 1996; Stice \& Shaw, 2004; Weiss, 1995). Underlying the intricate relationships surrounding body weight and its associated problems are weight perception and weight control behavior.

Treating obesity involves weight loss. However, a significant proportion of overweight persons are not engaging in weight control behaviors (Serdula et al., 1993; Williamson, Serdula, Anda, Levy, \& Byers, 1992) In contrast, a substantial proportion of those who are of normal weight or underweight are engaging in weight control behaviors, some

\footnotetext{
* Present address: University of Arkansas for Medical Sciences, Fay Boozman College of Public Health, Department of Health Education and Health Behavior, 4301 West Markham Street, \#820, Little Rock, AR 72205, USA. Tel.: +1 501526 6720; fax: +1 5015266709.

E-mail address: khk@uams.edu.
} 
of which are indicative of eating disorder symptomology (Serdula et al., 1993; Williamson et al., 1992). A reason for these discrepancies between actual body weight and weight control behavior is weight perception. Weight perception, or how one perceives her weight appropriateness, is strongly related with weight loss behavior, independent of actual body weight (Crawford \& Campbell, 1999; Forman, Trowbridge, Gentry, Marks, \& Hogelin, 1986; Serdula et al., 1993). Thus, better understanding weight perception can inform the creation of future interventions aimed to promote healthy body weight and healthy body weight perception.

Actual body weight is one of several factors that shape how one perceives her/his weight (Chang \& Christakis, 2001, 2003). Predictable patterns of weight perception and weight control behavior by gender, age, race/ethnicity, income, and education have been demonstrated (French \& Jeffery, 1997; French et al., 1997), (Chang \& Christakis, 2001, 2003). There are several hypotheses as to why weight perception and weight control behavior varies by these social factors. Sociocultural norms of thinness may pressure certain population subgroups, such as younger white women, more than others. Some population subgroups, such as men or older adults, may not be as affected because the norms may be specific by gender, age, and other variables (Crawford \& Campbell, 1999; Williamson et al., 1992). Standards of acceptable weight may also vary by culture, for which race/ethnicity can serve as a crude proxy (Rand \& Kuldau, 1990; Serdula et al., 1993). Body weight perception's relationship with social factors may also be due to status recognition and identification, with thinness being associated with higher socioeconomic status (Chang \& Christakis, 2003). From the literature on social factors, weight perception, and weight control behavior emerges a description of body weight as a rich social display of societal norms, culture, and status (Chang \& Christakis, 2003). Thus better understanding the social processes involved in weight perception and weight control behavior has tremendous potential in advancing research and practice concerning body weight. A significant social factor that has not been thoroughly examined in relationship to weight perception and weight control behaviors is religion. Religion, in this paper, is defined as the beliefs, practices, emotions, and relationships individuals have with the sacred, and the organization of these beliefs, practices, emotions, and relationships into rituals and activities (Zinnbauer et al., 1997).

Religion is a defining force in American society. Recent polls report that $90 \%$ of men and $95 \%$ of women believe in God, $30-42 \%$ of adults (72 million) attend church or synagogue weekly, and $85 \%$ report that religion is at least fairly important in their own lives (Poll, 2001; Worldwide, 2000). Religious beliefs about political issues and family also influence the cultural milieu on issues concerning abortion, sexuality, marriage, fertility, and childrearing. Recently, examinations of religion's influence have expanded to its relationship with health (Ellison \& Levin, 1998; Powell, Shahbi, \& Thoresen, 2003), and have reported religion's significant relationships with body weight (Ferraro, 1998; Kim, Sobal, \& Wethington, 2003), and its significant role in eating disorders (Morgan, Affleck, \& Solloway, 1990; Richards et al., 1997; Smith, Richards, \& Maglio, 2004; Warren et al., 1994). However, weight perception and weight loss behaviors have not been thoroughly examined in relationship to religion. Religion may be related to weight perception and weight control behavior in several ways. Certain religious groups encompass intricate systems of social norms, values, and experiences that define religious group members and their relationship to the larger society (Shatenstein \& Ghadirian, 1998). In contrast to mainstream society's norms concerning body weight, some religious groups may promote body acceptance and thus differential weight perceptions than the majority society (Groesz, Levine, \& Murnen, 2002; Harrison \& Cantor, 1997; Lavin \& Cash, 2001; Shaw \& Waller, 1995). Through providing a social enclave from societal norms of thinness, religious institutions may protect their adherents from overestimating their body weight. Thus religious adherents may not perceive their weights as heavier than they actually are, and may even perceive their weights as thinner than actuality. Consequently, the more religious may practice less weight control behavior than those not protected from social pressures to be thin. Believing that one has a relationship with a divine being who loves them personally and unconditionally may serve as a source of self-worth other than the physical body (Ellison \& Levin, 1998; Sherkat \& Ellison, 1999). Being thin endows one with sexual confidence, power, and security, whereas being overweight makes one untrustworthy, ugly, and weak (Brumberg, 2000). Thus social influences about the body encompass the meta-message that those who have the 'ideal' body have greater worth. Since the body ideal encompasses thinness, dieting is subsequently used to gain self-worth through striving for the attainment of a thin body (Brumberg, 2000; McAllister \& Caltabiano, 1994; Monteath \& McCabe, 1997; Tiggemann, 1991). Practicing religious beliefs, or 'doing' religion through supporting others could also give participants a sense of worth. Religious adherents would thus not only derive self-worth from a deity's acceptance, but also from their service and kindness to others (Commerford \& Reznikoff, 1996; Ellison, 1993). Thus, those who are more religious may be less likely to overestimate their body weight, and may even perceive their body weight as thinner than actuality compared to those who are less religious. Religion may also offer an alternative source of control other than the body. Controlling the body through dieting has 
been connected with perceived control (Dalgleish et al., 2001; Weiss \& Ebert, 1983; Xinaris \& Boland, 1990). Religion may be related to decreased weight control behavior through offering the religious adherent an alternative source of control other than the body. Communicating with deity through prayer, meditation, and song serves to increase perceived control by offering a means through which the believer can petition for changes in circumstances that would otherwise seem beyond their control (Ellison \& Levin, 1998; Sherkat \& Ellison, 1999).

\subsection{Religion, weight perception, and weight control behavior}

To the author's knowledge, religion's relationship with weight perception has not been directly examined. However, a few studies have explored religion's relationship with body perception. A study of the Old Order Amish, a conservative Protestant community, reported that older respondents overestimated their body size, whereas the young and those of normal weight reported no body perception distortion (Platte, Zelten, \& Stunkard, 2000). To a lesser extent than a religious community living separately from Western industrialized society, general religiousness within mainstream society may serve as a protective social enclave from the sociocultural pressures of ideal body shape that vulnerable young women face.

Although some weight control programs have religious components, such as Christian dieting programs (Winner, 2000) and Overeaters Anonymous (i.e. references to a "higher power") (Lester, 1999; Weiner, 1998; Westphal \& Smith, 1996), the relationships between religion and weight control behavior are also unclear. In an adolescent sample, there was a small association between increased religiosity and less unhealthy weight loss practices (Neumark-Sztainer, Story, $\&$ French, 1997). However, there was no relationship between religion and weight control concern in an undergraduate sample (Wechsler, Rohman, \& Solomon, 1981).

\subsection{Study purpose}

There are several hypotheses as to why religion may be related to weight perception and weight control behavior, but the evidence is not clear as to whether there is an empirical relationship between religion and these variables. Some studies have examined the relationship between different aspects of religion, body perception, and weight control behavior, but have not used nationally representative samples. Past research has also not taken into account religion's multiple aspects; some aspects of religion may be related to weight perception and weight control behavior, whereas others may not. Thus using a national sample, this study examined whether multiple measures of religion were related to weight perception and weight control behavior. Given that religion may provide a social enclave from societal norms regarding body weight, and serve as a source of worth and control other than through the body, it was hypothesized that those with greater reported religiosity (attendance/practice, social support, commitment, application, identity) would underestimate their body weight (perceive their weights as thinner than actuality), and report less weight control behavior. Those who affiliated themselves with a religious denomination were also hypothesized to underestimate their weight and report less weight control behavior compared to those specifying no religious preference.

\section{Methods}

Data from the National Survey of Midlife Development in the United States (MIDUS) was analyzed. A crosssectional study conducted in 1995, MIDUS examined how adult life changes are related with physical, psychological, and social health. MIDUS consisted of two parts: a telephone survey and a mailed questionnaire. Households were selected with random digit dialing and then one adult per household was randomly selected. The sample was nationally representative of the English-speaking, noninstitutionalized U. S. population ages 25-74 years with telephones.

In the MIDUS telephone interview, respondents were interviewed for approximately $40 \mathrm{~min}$ and were subsequently mailed a written questionnaire. The response rate for completing both parts of the survey was $61 \%$. The 3032 respondents who completed both parts of the survey were used in the analysis.

\subsection{Independent variables}

Religion is a complex, multidimensional construct, and there is little consensus about how religion should be conceptualized and measured. Prior literature (Jacobson, 1998; Smith, 1990; Steensland et al., 2000) and relevance to 
the study's hypotheses were considered in deciding how religion was conceptualized in the present study. The religion items in the MIDUS data were comprised of six categories: denomination, religious attendance/practice, religious social support, religious commitment, religious application, and religious identity.

Denomination questions asked respondents what their religious preference was, and for this analysis the denominations were collapsed to maximize a meaningful interpretation of denomination's possible relationship with body weight. Given the considerations of previous researchers (Smith, 1990; Steensland et al., 2000), religious denomination for this analysis was grouped into six categories: Catholic, Conservative Protestant, Mainline Protestant, Jewish, Other, and No Religious Preference.

Religious Attendance/Practice is a standard component of religiosity that is often analyzed (Chadwick \& Garrett, 1995; De Vaus \& McAllister, 1987). MIDUS respondents were asked to choose from 5 categories describing how often they attend religious services, with higher scores indicating greater religious attendance/practice.

Religious Application was assessed by asking respondents how often they asked themselves what their religious beliefs suggest they should do in making daily life decisions, with higher scores indicating stronger religious application.

Religious Social Support was assessed through the question, 'How often do you seek religious comfort', with four response categories ranging from 'never' to 'often'.

Religious Identity $(\alpha=.84)$ was a continuous multi-item measure constructed from four single item categorical variables. An example of these questions is, "How important do you think it is for people of your religion to marry other people who are the same religion?" Higher scores indicated stronger religious identity.

Table 1

Weighted sample characteristics

\begin{tabular}{|c|c|c|}
\hline \multirow[t]{2}{*}{ Variable } & \multicolumn{2}{|l|}{ Mean or percent } \\
\hline & Men $(n=1471)$ & Women $(n=1561)$ \\
\hline \multicolumn{3}{|l|}{ Demographics } \\
\hline Age (years) & $45 \pm 12.5$ & $45 \pm 14.3$ \\
\hline Race/ethnicity (white) & $74 \%$ & $75 \%$ \\
\hline \multicolumn{3}{|l|}{ Education } \\
\hline Some grade-high school & $13 \%$ & $14 \%$ \\
\hline High school & $36 \%$ & $40 \%$ \\
\hline Some college & $24 \%$ & $26 \%$ \\
\hline College or more & $28 \%$ & $20 \%$ \\
\hline Income $^{\mathrm{a}}(\$)$ & $51,487 \pm 33,063$ & $41,928 \pm 34,694$ \\
\hline \multicolumn{3}{|l|}{ Independent variables } \\
\hline \multicolumn{3}{|l|}{ Denomination } \\
\hline Catholic & $26 \%$ & $24 \%$ \\
\hline Conservative protestant & $32 \%$ & $38 \%$ \\
\hline Mainline protestant & $22 \%$ & $23 \%$ \\
\hline Jewish & $2 \%$ & $2 \%$ \\
\hline Other & $5 \%$ & $6 \%$ \\
\hline No religious preference & $12 \%$ & $7 \%$ \\
\hline Religious attendance/practice ( $1=$ never, $5=>1 /$ wk $)$ & $2.6 \pm 1.3$ & $2.9 \pm 1.4$ \\
\hline Religious social support (1=low, 4=high) & $2.5 \pm 1.1$ & $3.1 \pm 1.1$ \\
\hline Religious application (1=low, 4=high) & $2.5 \pm 1.1$ & $2.9 \pm 1.1$ \\
\hline Religious commitment (1=low, 4=high) & $2.9 \pm 0.7$ & $3.1 \pm 0.7$ \\
\hline Religious identity (1=low, 4=high) & $2.5 \pm 0.8$ & $2.8 \pm 0.9$ \\
\hline \multicolumn{3}{|l|}{ Dependent variable } \\
\hline Weight perception (very underweight) & $1 \%$ & $0 \%$ \\
\hline Weight perception (somewhat underweight) & $7 \%$ & $4 \%$ \\
\hline Weight perception (about the right weight) & $35 \%$ & $28 \%$ \\
\hline Weight perception (somewhat overweight) & $50 \%$ & $50 \%$ \\
\hline Weight perception (very overweight) & $7 \%$ & $18 \%$ \\
\hline BMI & $27 \pm 4.3$ & $27 \pm 6.7$ \\
\hline Intentional weight loss (yes) & $18 \%$ & $25 \%$ \\
\hline
\end{tabular}

\footnotetext{
${ }^{\text {a }}$ Imputed.
} 
Religious Commitment $(\alpha=.88)$ was a sum of four questions about how religious and spiritual respondents considered themselves, and how important they considered religion and spirituality to be in their lives. Higher scores indicated greater commitment.

\subsection{Dependent variables}

Weight perception was conceptualized as 'correspond' (weight perception is concordant with national standards), 'underassess' (weight perception is in a lighter category than national standards), and 'overassess' (weight perception is in a higher category than national standards). Several steps were taken to conceptualize weight perception in this manner. First, self-reported weight and height were used to calculate Body Mass Index (BMI) and categorized 'obese', 'overweight', 'normal', and 'underweight' based on national standards (Status, 1995). Second, the responses of the single item question: "On weight, which of the following do you consider yourself - 'very underweight', 'somewhat underweight', 'about the right weight', 'somewhat overweight', or 'very overweight'?" were re-categorized using body weight category terminology. Weight perception categories of 'very underweight' and 'somewhat underweight' were re-categorized as 'underweight'; 'about the right weight' was re-categorized as 'normal'; 'somewhat overweight' was re-categorized as 'overweight'; and 'very overweight' was re-categorized as 'obese'. Then, the difference between weight perception and BMI was calculated, and respondents were grouped by categories 'correspond', 'underassess', and 'overassess'.

To assess weight control behavior, respondents were asked, "During the past 12 months, did you lose $10 \mathrm{lb}$ or more by diet, exercise or change in lifestyle?", to which respondents answered either 'yes' or 'no'.

\subsection{Demographic variables}

Demographics of gender, age, race/ethnicity, education, and total household income were examined (Cooks \& Descutner, 1993; Feingold \& Mazzella, 1998; Huon \& Lim, 2000; Moulding \& Hepworth, 2001; Slade, 1985). Using the mean income of gender, marital status, education, age, employment, and race, missing values for income were imputed (Lachman \& Weaver, 1998; Little \& Rubin, 1987). Cases where income was imputed were not significantly related to weight perception and weight control behavior.

\subsection{Analysis}

Descriptive univariate frequencies were examined for all sample characteristics (Table 1), in addition to cross-tabs comparing self-evaluation of weight status with classification of BMI by national standards (obese $=\mathrm{BMI} \geq 30$; overweight $=$ BMI 25-29.9; normal $=$ BMI 18.5-24.9; underweight $=\mathrm{BMI}<18.5)($ Table 2) $($ Status, 1995). Then a series of logistic regression models were conducted to systematically examine relationships between religion, weight perception, and weight control behavior. Religion variables were entered separately in assessing their relationships to weight perception and weight control behavior because the complex nature of religion is such that different dimensions of religion have different pathways in their effects on health (Koenig et al., 1997). MIDUS sampling weights were used in all analyses to adjust for possible selection and nonresponse bias.

All models assessing religion's relationship with weight perception controlled for BMI and were conducted separately by gender. To assess religion's relationship with the accuracy of self-classified weight status (relative to national standards), "correspond" was used as the baseline category of comparison. Thus results regarding weight

Table 2

Comparison of self-evaluation of weight status with classification of BMI by national standards* $(N=3032)$

\begin{tabular}{lccrr}
\hline Medical status & Overweight & Just right & Underweight & Total \\
\hline Obese & $345(10.2)$ & $353(10.5)$ & $17(0.5)$ & $6(0.2)$ \\
Overweight & $75(2.2)$ & $972(28.9)$ & $217(6.4)$ & $785(23.3)$ \\
Normal & $9(0.3)$ & $433(12.9)$ & $9(0.3)$ & $117(3.5)$ \\
Underweight & $0(0)$ & $0(0)$ & $1028(30.5)$ & $21(0.6)$ \\
Total & $429(12.7)$ & $1758(52.2)$ & $154(4.6)$ \\
\hline
\end{tabular}

*Obese (BMI $\geq 30$ ); Overweight (BMI 25-29.9); Normal (BMI 18.5-24.9); Underweight (BMI<18.5). 
Table 3

Regression of religion and spirituality on weight perception: underassessment ${ }^{\mathrm{a}}$

\begin{tabular}{|c|c|c|c|c|}
\hline & \multicolumn{2}{|l|}{ Women } & \multicolumn{2}{|l|}{ Men } \\
\hline & \multirow{2}{*}{$\begin{array}{l}\text { Model } 1 \\
\text { Controlling for BMI } \\
\text { (underassess vs. } \\
\text { correspond) }\end{array}$} & \multirow{2}{*}{$\begin{array}{l}\text { Model } 2 \\
\text { Controlling for BMI age, race/ethnicity } \\
\text { education, income (underassess vs. } \\
\text { correspond) }\end{array}$} & \multirow{2}{*}{$\begin{array}{l}\text { Model } 1 \\
\text { Controlling for BMI } \\
\text { (underassess vs. } \\
\text { correspond) }\end{array}$} & \multirow{2}{*}{$\begin{array}{l}\text { Model } 2 \\
\text { Controlling for BMI age, race/ethnicity } \\
\text { education, income (underassess vs. } \\
\text { correspond) }\end{array}$} \\
\hline & & & & \\
\hline \multicolumn{5}{|l|}{ Religion variables } \\
\hline $\begin{array}{l}\text { Denomination }{ }^{\mathrm{b}} \\
\text { (catholic) }\end{array}$ & $0.50(0.18,1.4)$ & $0.66(0.21,2.0)$ & $0.80(0.47,1.3)$ & $0.85(0.49,1.5)$ \\
\hline $\begin{array}{l}\text { Denomination } \\
\text { (conservative } \\
\text { protestant) }\end{array}$ & $1.4(0.56,3.4)$ & $1.0(0.37,2.8)$ & $1.2(0.70,1.9)$ & $1.1(0.65,1.9)$ \\
\hline $\begin{array}{l}\text { Denomination } \\
\text { (mainline } \\
\text { protestant) }\end{array}$ & $1.1(0.44,2.9)$ & $1.5(0.53,4.4)$ & $1.1(0.66,1.9)$ & $1.1(0.65,1.9)$ \\
\hline $\begin{array}{l}\text { Denomination } \\
\text { (Jewish) }\end{array}$ & $0(0,999)$ & $0(0,999)$ & $0.63(0.15,2.6)$ & $1.2(0.28,5.0)$ \\
\hline $\begin{array}{l}\text { Denomination } \\
\text { (other) }\end{array}$ & $0.61(0.14,2.6)$ & $0.51(0.11,2.4)$ & $0.66(0.28,1.6)$ & $0.55(0.22,1.4)$ \\
\hline $\begin{array}{l}\text { Religious } \\
\text { attendance/ } \\
\text { practice }\end{array}$ & $1.1(0.93,1.3)$ & $1.1(0.89,1.3)$ & $1.1(0.99,1.2)$ & $1.1(0.99,1.3)$ \\
\hline $\begin{array}{l}\text { Religious social } \\
\text { support }\end{array}$ & $1.1(0.85,1.3)$ & $1.1(0.83,1.4)$ & $1.1(0.99,1.3)$ & $1.1(0.97,1.1)$ \\
\hline $\begin{array}{l}\text { Religious } \\
\text { commitment }\end{array}$ & $1.2(1.1,1.3)^{* *}$ & $1.2(1.1,1.4)^{* *}$ & $1.0(0.98,1.1)$ & $1.0(0.97,1.1)$ \\
\hline $\begin{array}{l}\text { Religious } \\
\text { application }\end{array}$ & $1.1(0.83,1.3)$ & $1.1(0.84,1.4)$ & $1.2(1.0,1.3)^{*}$ & $1.2(1.0,1.4)^{*}$ \\
\hline $\begin{array}{l}\text { Religious } \\
\text { identity }\end{array}$ & $1.1(1.0,1.2)^{*}$ & $1.0(0.95,1.1)$ & $1.0(0.96,1.1)$ & $1.0(0.95,1.1)$ \\
\hline
\end{tabular}

$* * p<.01 ; * p<.05$.

${ }^{\text {a }}$ Cells of the table represent odds ratios (95\% confidence interval).

b 'No religious preference' is the reference category for denomination.

perception refer to the odds of underassessment vs. correspondence, or overassessment vs. correspondence. To test whether those with higher levels of religion underestimated or overestimated (compared to corresponded with) their weight compared to those with lower levels of religion, weight perception was regressed on the religion variables using PROC LOGISTIC from SAS 8.2 (Tables 3 and 4, Model 1). Thus Model 1 included religion as the independent variable, BMI as a control variable, and weight perception (underassess vs. correspond, or overassess vs. correspond) as the dependent variable. These relationships were assessed separately by gender. Model 2 contained all the variables in Model 1, plus demographics (age, race/ethnicity, education and income) (Tables 3 and 4, Model 2). All Models were run separately by gender and controlled for BMI.

Logistic regressions were also conducted to examine religion's relationship with weight control behavior. To adjust for the need of intentional weight loss, BMI was controlled in all analyses of weight control behavior and religion (Croll \& Kearney-Cooke, 2003; Gunewardene, Huon, \& Zheng, 2001). In the first model, weight control behavior was regressed on the religion variables (Table 5, Model 1). Thus Model 1 included religion as the independent variable, BMI as a control variable, and weight control behavior as the dependent variable. These relationships were assessed separately by gender. Model 2 contained all the variables in Model 1, plus demographics (age, race/ethnicity, education and income) (Table 5, Model 2).

\section{Results}

Weighted descriptive statistics of the sample are presented in Table 1 . There were slightly more women than men in the sample, the average age for both women and men was 47 , and the majority of the sample was white. Fifty-eight 
Table 4

Regression of religion and spirituality on weight perception: overassessment ${ }^{\mathrm{a}}$

\begin{tabular}{|c|c|c|c|c|}
\hline & \multicolumn{2}{|l|}{ Women } & \multicolumn{2}{|l|}{ Men } \\
\hline & \multirow{2}{*}{$\begin{array}{l}\text { Model } 1 \\
\text { Controlling for BMI } \\
\text { (overassess vs. } \\
\text { correspond) }\end{array}$} & \multirow{2}{*}{$\begin{array}{l}\text { Model } 2 \\
\text { Controlling for BMI age, race/ethnicity } \\
\text { education, income (overassess vs. } \\
\text { correspond) }\end{array}$} & \multirow{2}{*}{$\begin{array}{l}\text { Model } 1 \\
\text { Controlling for BMI } \\
\text { (overassess vs. } \\
\text { correspond) }\end{array}$} & \multirow{2}{*}{$\begin{array}{l}\text { Model } 2 \\
\text { Controlling for BMI age, race/ethnicity } \\
\text { education, income (overassess vs. } \\
\text { correspond) }\end{array}$} \\
\hline & & & & \\
\hline \multicolumn{5}{|c|}{ Religion variables } \\
\hline $\begin{array}{l}\text { Denomination }{ }^{\mathrm{b}} \\
\text { (catholic) }^{\text {calc }}\end{array}$ & $1.2(0.73,2.1)$ & $1.4(0.79,2.3)$ & $0.83(0.37,1.9)$ & $0.86(0.36,2.0)$ \\
\hline $\begin{array}{l}\text { Denomination } \\
\text { (conservative } \\
\text { protestant) }\end{array}$ & $1.2(0.69,2.0)$ & $1.3(0.79,2.3)$ & $0.68(0.30,1.6)$ & $0.78(0.32,1.9)$ \\
\hline $\begin{array}{l}\text { Denomination } \\
\text { (mainline } \\
\text { protestant) }\end{array}$ & $1.1(0.64,1.9)$ & $1.1(0.63,1.9)$ & $0.88(0.38,2.1)$ & $0.85(0.35,2.1)$ \\
\hline $\begin{array}{l}\text { Denomination } \\
\text { (Jewish) }\end{array}$ & $3.1(1.3,7.4)^{* *}$ & $2.9(1.2,7.0)^{*}$ & $2.7(0.73,10.2)^{*}$ & $2.0(0.49,8.2)$ \\
\hline $\begin{array}{l}\text { Denomination } \\
\text { (other) }\end{array}$ & $1.2(0.58,2.3)$ & $1.1(0.56,2.3)$ & $0.70(0.18,2.7)$ & $0.75(0.19,3.0)$ \\
\hline $\begin{array}{l}\text { Religious } \\
\text { attendance/ } \\
\text { practice }\end{array}$ & $0.99(0.90,1.1)$ & $1.0(0.91,1.1)$ & $1.1(0.90,1.3)$ & $1.0(0.83,1.2)$ \\
\hline $\begin{array}{l}\text { Religious social } \\
\text { support }\end{array}$ & $0.96(0.86,1.1)$ & $0.99(0.88,1.1)$ & $1.0(0.84,1.3)$ & $0.98(0.78,1.2)$ \\
\hline $\begin{array}{l}\text { Religious } \\
\text { commitment }\end{array}$ & $1.0(0.96,1.1)$ & $1.0(0.97,1.1)$ & $1.0(0.94,1.1)$ & $1.0(0.92,1.1)$ \\
\hline $\begin{array}{l}\text { Religious } \\
\text { application }\end{array}$ & $1.1(1.0,1.3)^{*}$ & $1.2(1.0,1.3)^{* *}$ & $1.1(0.86,1.3)$ & $1.0(0.80,1.3)$ \\
\hline $\begin{array}{l}\text { Religious } \\
\text { identity }\end{array}$ & $0.99(0.95,1.0)$ & $1.0(0.97,1.0)$ & $1.0(0.95,1.1)$ & $1.0(0.93,1.1)$ \\
\hline
\end{tabular}

percent of women and $64 \%$ of men had at least some college education, with a greater proportion of men compared to women having a college education or more. Women reported an average household annual income of $\$ 43,122$, whereas men reported an average annual income of $\$ 53,840$. As a whole, the descriptive statistics appeared to represent the US population with the exception of education and income, which was somewhat higher than the national average in 1995 (Bureau, 1995).

Most of the sample was either Catholic or Protestant, and in contrast to women, a slightly greater proportion of men specified their religious preference to be either agnostic, atheist or of no religious preference. Among the religion items, women reported an overall greater religiosity than men, especially in the religious social support item and the religious commitment items.

The mean BMI for both women and men was 27 ; nearly $60 \%$ of the sample was either overweight or obese. The majority of the sample reported perceiving their weight as at least 'somewhat overweight', with $18 \%$ of women reporting themselves to be 'very overweight' compared to 7\% of men. About a quarter of the sample reported losing at least $10 \mathrm{lb}$ by diet, exercise, or change of lifestyle, with more women reporting weight control behavior than men.

A majority of the sample classified themselves in accordance with current national weight classification guidelines (Table 2). However, $37.1 \%$ of participants incorrectly classified their weight status, with $21.4 \%$ of participants underestimating and $15.7 \%$ of participants overestimating their weight.

Weight perception (underassessment vs. correspond) was regressed against the religion items in Model 1 (Table 3). For women, a significant relationship of weight perception with religious commitment and religious identity existed, with women reporting higher religiosity having greater odds of underestimating their weight. The relationship between greater religious commitment and weight underassessment remained after controlling for demographics. In men, those with higher levels of religious application had greater odds of underestimating their weight. This significant relationship persisted after demographics were controlled (Table 3). 
Table 5

Regression of religion and spirituality on intentional weight $\operatorname{loss}^{\mathrm{a}}$

\begin{tabular}{|c|c|c|c|c|}
\hline & \multicolumn{2}{|l|}{ Women } & \multicolumn{2}{|l|}{ Men } \\
\hline & \multirow{2}{*}{$\begin{array}{l}\text { Model } 1 \\
\text { Controlling for } \\
\text { BMI }\end{array}$} & \multirow{2}{*}{$\begin{array}{l}\text { Model } 2 \\
\text { Controlling for BMI age, race/ethnicity } \\
\text { education, income }\end{array}$} & \multirow{2}{*}{$\begin{array}{l}\text { Model } 1 \\
\text { Controlling for } \\
\text { BMI }\end{array}$} & \multirow{2}{*}{$\begin{array}{l}\text { Model } 2 \\
\text { Controlling for BMI age, race/ethnicity } \\
\text { education, income }\end{array}$} \\
\hline & & & & \\
\hline \multicolumn{5}{|l|}{ Religion variables } \\
\hline Denomination $^{\mathrm{b}}$ (catholic) & $1.0(0.63,1.6)$ & $1.1(0.67,1.8)$ & $1.3(0.75,2.1)$ & $1.3(0.77,2.2)$ \\
\hline $\begin{array}{l}\text { Denomination (conservative } \\
\text { protestant) }\end{array}$ & $0.77(0.49,1.2)$ & $0.83(0.51,1.3)$ & $0.89(0.53,1.5)$ & $0.95(0.56,1.6)$ \\
\hline $\begin{array}{l}\text { Denomination (mainline } \\
\text { protestant) }\end{array}$ & $0.70(0.43,1.1)$ & $0.78(0.48,1.3)$ & $1.1(0.62,1.8)$ & $1.1(0.64,1.9)$ \\
\hline Denomination (Jewish) & $1.2(0.53,2.9)$ & $1.3(0.54,3.2)$ & $1.4(0.51,4.0)$ & $1.3(0.45,3.7)$ \\
\hline Denomination (other) & $0.66(0.34,1.3)$ & $0.58(0.30,1.1)$ & $0.77(0.33,1.8)$ & $0.72(0.30,1.7)$ \\
\hline Religious attendance/practice & $1.0(0.92,1.1)$ & $1.0(0.93,1.1)$ & $0.99(0.88,1.1)$ & $1.0(0.90,1.1)$ \\
\hline Religious social support & $1.0(0.90,1.1)$ & $1.0(0.93,1.2)$ & $1.0(0.90,1.2)$ & $1.0(0.92,1.2)$ \\
\hline Religious commitment & $1.0(0.97,1.1)$ & $1.0(0.99,1.1)$ & $1.0(0.96,1.1)$ & $1.0(0.97,1.1)$ \\
\hline Religious application & $1.1(0.95,1.2)$ & $1.1(0.99,1.2)$ & $0.90(0.79,1.0)$ & $0.92(0.80,1.1)$ \\
\hline Religious identity & $1.0(0.98,1.1)$ & $1.0(0.98,1.1)$ & $0.98(0.94,1.0)$ & $0.99(0.95,1.0)$ \\
\hline
\end{tabular}

Regarding weight perception's (overassessment vs. correspond) relationship with religion, Jewish women had a significantly larger odds of overestimating their weight compared to women of no religious preference. The magnitude of this relationship was rather large, and remained after controlling for demographics (Table 4). In women, a significant relationship also existed between religious application and weight overassessment, with women reporting greater religious application having greater odds of overestimating their body weight. Controlling for demographics did not change the significance or magnitude of the relationship. In men, there was also a significant relationship between Jewish denomination and weight overassessment, with Jewish men reporting greater odds of weight overassessment than men of no religious preference (Model 1, Table 4). However, this relationship did not remain significant after controlling for the demographic variables (Model 2, Table 4).

In regressing weight control behavior against the religion items, there were no significant relationships for either men or women (Table 5).

\section{Discussion}

Different aspects of religiosity were significantly related to weight perception in women and men. Women with greater religious commitment and men with greater religious application had greater odds of underestimating their body weight. These relationships remained significant after controlling for BMI, age, race/ethnicity, education, and income. These results partially support the hypothesis that those with greater reported religiosity would perceive their weights as thinner than their reported weight. However, there were significant relationships between measures of religiosity and weight overestimation that were not consistent with the study's hypothesis. The magnitude of the relationship between specifying a Jewish affiliation and weight overassessment in women was high, with those indicating a Jewish denomination having greater odds of overestimating their body weight compared to those with no religious preference. In addition, women reporting greater religious application had greater odds of overestimating their weight, compared to women with lower reported levels of religious application. There may be social and cultural norms unique to Judaism that may shape weight perception in women. Further studies need to be conducted to elucidate the connection between Judaism and body image in women. It is unclear why women with greater religious application would overestimate their weight. The confidence interval of the odds ratio includes a null effect; thus the significant relationship between religious application and weight overestimation in women may reflect a relationship where religious application is not significantly related to weight overestimation in women. 
These results are applicable to the English-speaking, noninstitutionalized U. S. population ages 25-74 years with telephones. Although the sample was predominately white with higher socioeconomic status, sampling weights were used to make the results nationally representative. Like many national data sets, however, the results from this study are not applicable to those in rural, disadvantaged areas.

There are several limitations to the study. Many aspects of religion were examined separately in their relationship to weight perception and intentional weight loss, thus multiple hypothesis testing may have produced significant results when they were due to chance alone. However, adjusting for multiple hypothesis testing using a Bonferonni procedure or another similar technique would have been an over-adjustment, especially given the high correlations between the religion variables (Keselman, Cribbie, \& Holland, 1999). Thus to guard against Type II error, Bonferonni adjustments were not conducted and multiple $p$-values were reported to permit readers to make their own decisions about interpreting $p$-values (Sobal, 1987).

Another limitation is that body weight was self-reported. The validity of self-reported weight and height is generally good (Bowman \& DeLucia, 1992; Stewart, 1982); however higher BMI values may have been underestimated (Stewart, Jackson, Ford, \& Beaglehole, 1987). If self-reported BMI was overestimated, then the discrepancy between actual body weight and weight perception would have been greater. For example, if a woman reported an actual body weight of 'overweight', and a weight perception of 'normal weight' then she underestimated her body weight, i.e. she perceived her weight as thinner than actuality. However, if she underestimated her actual body weight, i.e. if her actual body weight was really 'very overweight' (instead of 'overweight'), then her level of underestimation would have been higher, i.e. there would be an ever greater discrepancy between her actual weight and her perceived weight. Thus, the possible selfreport bias of overweight and obese individuals underestimating their actual body weight could have hidden the full magnitude and significance of the relationships between religion and weight perception.

Further limitations include a single item measure to assess weight control behavior (more comprehensive measures would have been more beneficial), and the cross-sectional nature of the data, which does not elucidate the direction of causality. However, given these limitations, the current study used a national sample to examine how multiple aspects of religion are related to weight perception and weight control behavior. Previous studies have not examined religion's relationship with weight perception, and the few that have examined religion's relationship with variables related to weight perception and weight control behavior have not used national samples or comprehensive measures of religion. Thus, the current study more broadly elucidates religion's relationship with weight perception and weight control behavior than prior work.

Practitioners can benefit from this work by realizing that in general, religion may not play a large role in weight perception and weight control behavior, but may affect the weight perception of some religious individuals in complex ways. Realizing religion's intricacies in working with more religious clients will help the practitioner have a more realistic view of religion's possible role, i.e. that religious beliefs are not a simple uniform construct, but rather multidimensional in nature. Thus, in understanding the complexity of religious faith, researchers and practitioners will be able to be more sensitive in developing and utilizing methods in understanding and improving health.

\section{Acknowledgments}

The author would like to thank Jeffery Sobal for his help in revising the manuscript, and the Division of Nutritional Sciences at Cornell University for the financial support in part by the National Institutes of Health Training Grant DK07158.

\section{References}

Bowman, R. L., \& DeLucia, J. L. (1992). Accuracy of self-reported weight: A meta-analysis. Behavior Therapy, 23, $637-655$.

Brumberg, J. J. (2000). Fasting girls: The history of anorexia nervosa. New York: Vintage Books.

Bureau, U. S. C. (1995). Statistical abstract of the United States: The national data book.

Chadwick, B. A., \& Garrett, H. D. (1995). Women's religiosity and employment: The LDS experience. Review of Religious Research, 36, $277-293$.

Chang, V. W., \& Christakis, N. A. (2001). Extent and determinants of discrepancy between self-evaluations of weight status and clinical standards. Journal of General Internal Medicine, 16(8), 538-543.

Chang, V. W., \& Christakis, N. A. (2003). Self-perception of weight appropriateness in the United States. American Journal of Preventive Medicine, 24(4), 332-339.

Commerford, M. C., \& Reznikoff, M. (1996). Relationship of religion and perceived social support to self-esteem and depression in nursing home residents. The Journal of Psychology, 130, 35-50. 
Cooks, L., \& Descutner, D. (1993). Different paths from powerlessness to empowerment: A dramatistic analysis of two eating disorder therapies. Western Journal of Communication, 57, 494-514.

Crawford, D., \& Campbell, K. (1999). Lay definitions of ideal weight and overweight. International Journal of Obesity, 23(7), 738-745.

Croll, J. K., \& Kearney-Cooke, A. (2003). Dieting frequency among college females: Association with disordered eating, body image and related psychological problems. Journal of Psychosomatic Research, 52, 129-136.

Dalgleish, T., Tchanturia, K., Serpell, L., Hems, S., Silva, P., \& Treasure, J. (2001). Perceived control over events in the world in patients with eating disorders: A preliminary study. Personality and Individual Differences, 31, 453-460.

De Vaus, D., \& McAllister, I. (1987). Gender differences in religion: A test of the structural location theory. American Sociological Review, 52, 472-481.

Ellison, C. G. (1993). Religious involvement and self-perception among black Americans. Social Forces, 71, 1027-1055.

Ellison, C. G., \& Levin, J. S. (1998). The religion-health connection: Evidence, theory, and future directions. Health Education and Behavior, 25(6), 700-720.

Feingold, A., \& Mazzella, R. (1998). Gender differences in body image are increasing. Psychological Science, 9, $190-195$.

Ferraro, K. F. (1998). Firm believers? Religion, body weight, and well being. Review of Religious Research, 39, $224-244$.

Flegal, K. M., Carroll, M. D., Ogden, C. L., \& Johnson, C. L. (2002). Prevalence and trends in obesity among US adults, 1999-2000. Journal of the American Medical Association, 288(14), 1723-1727.

Forman, M. R., Trowbridge, F. L., Gentry, E. M., Marks, J. S., \& Hogelin, G. C. (1986). Overweight adults in the United States: The behavioral risk factor surveys. American Journal of Clinical Nutrition, 44(3), 410-416.

French, S. A., \& Jeffery, R. W. (1997). Current dieting, weight loss history, and weight suppression: Behavioral correlates of three dimensions of dieting. Addictive Behaviors, 22(1), 31-44.

French, S. A., Story, M., Neumark-Sztainer, D., Downes, B., Resnick, M., \& Blum, R. (1997). Ethnic differences in psychosocial and health behavior correlates of dieting, purging, and binge eating in a population-based sample of adolescent females. International Journal of Eating Disorders, 22 (3), 315-322.

Groesz, L. M., Levine, M. P., \& Murnen, S. K. (2002). The effect of experimental presentation of thin media images on body satisfaction: A metaanalytic review. International Journal of Eating Disorders, 31, 1-16.

Gunewardene, A., Huon, G. F., \& Zheng, R. (2001). Exposure to westernization and dieting: A cross-cultural study. International Journal of Eating Disorders, 29, 289-293.

Harrison, K., \& Cantor, J. (1997). The relationship between media consumption and eating disorders. Journal of Communication, $47,40-67$.

Huon, G., \& Lim, J. (2000). The emergence of dieting among female adolescents: Age, body mass index, and seasonal effects. International Journal of Eating Disorders, 28, 221-225.

Jacobson, C. K. (1998). Religiosity and prejudice: An update and denominational analysis. Review of Religious Research, 39, $264-272$.

Keselman, H. E. J., Cribbie, R., \& Holland, B. (1999). The pairwise multiple comparison multiplicity problem: An alternative approach to familywise and listwise Type I error control. Psychological Methods, 4, 58-69.

Kim, K. H., Sobal, J., \& Wethington, E. (2003). Religion and body weight. International Journal of Obesity, 27(4), $469-477$.

Koenig, H. G., Hays, J. C., George, L. K., Blazer, D. G., Larson, D. B., \& Landerman, L. R. (1997). Modeling the cross-sectional relationships between religion, physical health, social support, and depressive symptoms. American Journal of Geriatric Psychiatry, 5(2), $131-144$.

Lachman, M. E., \& Weaver, S. L. (1998). The sense of control as a moderator of social class differences in health and well-being. Journal of Personality and Social Psychology, 74, 763-773.

Lavin, M. A., \& Cash, T. F. (2001). Effects of exposure to information about appearance stereotyping and discrimination on women's body images International Journal of Eating Disorders, 29, 51-58.

Lester, R. J. (1999). Let go and let God. In J. Sobal \& D. Maurer (Eds.), Interpreting weight (pp. 139-164). Hawthorne, NY: Aldine De Gruyter.

Little, R. J. A., \& Rubin, D. B. (1987). Statistical analysis with missing data: Wiley.

McAllister, R., \& Caltabiano, M. L. (1994). Self-esteem, body-image, and weight in noneating-disordered women. Psychological Reports, 75, $1339-1343$.

Mokdad, A. H., Ford, E. S., Bowman, B. A., Dietz, W. H., Vinicor, F., Bales, V. S., et al. (2003). Prevalence of obesity, diabetes, and obesity-related health risk factors, 2001. Journal of the American Medical Association, 289(1), 76-79.

Monteath, S. A., \& McCabe, M. P. (1997). The influence of societal factors on female body image. The Journal of Social Psychology, 137, 708-727.

Morgan, C. S., Affleck, M., \& Solloway, O. (1990). Gender role attitudes, religiosity, and food behavior: Dieting and bulimia in college women. Social Science Quarterly, 71, 142-151.

Moulding, N., \& Hepworth, J. (2001). Understanding body image disturbance in the promotion of mental health: A discourse analytic study. Journal of Community and Applied Social Psychology, 11, 305-317.

Neumark-Sztainer, D., Story, M., \& French, S. A. (1997). Psychosocial correlates of health compromising behaviors among adolescents. Health Education Research, 12, 37-52.

Newman, D. L., Moffitt, T. E., Caspi, A., Magdol, L., Silva, P. A., \& Stanton, W. R. (1996). Psychiatric disorder in a birth cohort of young adults: Prevalence, comorbidity, clinical significance, and new case incidence from ages 11 to 21. Journal of Consulting and Clinical Psychology, 64(3), 552-562.

Platte, P., Zelten, J. F., \& Stunkard, A. J. (2000). Body image in the old order Amish: A people separate from "the world". International Journal of Eating Disorders, 28(4), 408-414.

Poll, G. (2001). Gallup poll. United States: The Roper Center for Public Opinion Research.

Powell, L. H., Shahbi, L., \& Thoresen, C. E. (2003). Religion and spirituality: Linkages to physical health. American Psychologist, $58,36-52$.

Rand, C. S. W., \& Kuldau, J. M. (1990). The epidemiology of obesity and self-defined weight problem in the general population: Gender, race, age, and social class. International Journal of Eating Disorders, 9, 329-343. 
Richards, P. S., Hardman, R. K., Frost, H. A., Berrett, M. E., Clark-Sly, J. B., \& Anderson, D. K. (1997). Spiritual issues and interventions in the treatment of patients with eating disorders. Eating Disorders, 5(4), 261-279.

Serdula, M. K., Collins, M. E., Williamson, D. F., Anda, R. F., Pamuk, E., \& Byers, T. E. (1993). Weight control practices of U.S. adolescents and adults. Annals of Internal Medicine, 119(7 Pt 2), 667-671.

Shatenstein, B., \& Ghadirian, P. (1998). Influences on diet, health behaviours and their outcome in select ethnocultural and religious groups. Nutrition, 14(2), 223-230.

Shaw, J., \& Waller, G. (1995). The media's impact on body image: Implications for prevention and treatment. Eating Disorders, 3(2), 115-123.

Sherkat, D. E., \& Ellison, C. G. (1999). Recent developments and current controversies in the sociology of religion. Annual Review of Sociology, 25, 363-394.

Slade, P. (1985). A review of body-image studies in anorexia nervosa and bulimia nervosa. Journal of Psychiatric Research, 19, $255-265$.

Smith, M. H., Richards, P. S., \& Maglio, C. J. (2004). Examining the relationship between religious orientation and eating disturbances. Eating Behaviors, 5(2), 171-180.

Smith, T. W. (1990). Classifying protestant denominations. Review of Religious Research, 31, 225-245.

Sobal, J. (1987). Health concerns of young adolescents. Adolescence, 22(87), 739-750.

Status, W. E. C. o. P. (1995). The use and interpretation of anthropometry: Report of a WHO expert committee (World Health Organization Technical Report Series 854). Geneva, Switzerland: World Health Organization.

Steensland, B., Park, J. Z., Regnerus, M. D., Robinson, L. D., Wilcox, W. B., \& Woodberry, R. D. (2000). The measure of american religion: Toward improving the state of the art. Social Forces, 1-28.

Stewart, A. L. (1982). The reliability and validity of self-reported weight and height. Journal of Chronic Disease, 35, $295-309$.

Stewart, A. W., Jackson, R. T., Ford, M. A., \& Beaglehole, R. (1987). Underestimation of relative weight by use of self-reported height and weight. American Journal of Epidemiology, 125(1), 122-126.

Stice, E., \& Shaw, H. (2004). Eating disorder prevention programs: A meta-analytic review. Psychological Bulletin, $130(2), 206-227$.

Tiggemann, M. (1991). Body-size dissatisfaction: Individual differences in age and gender, and relationship with self-esteem. Personality and Individual Differences, 13, 39-43.

Warren, W. G., Jackson, C. C., Thornton, C., Russell, J., Touyz, S. W., \& Beumont, P. J. (1994). A study of the relation between eating disorder and death concern. Australian New Zealand Journal of Psychiatry, 28(3), 463-468.

Wechsler, H., Rohman, M., \& Solomon, L. (1981). Emotional problems and concerns of New England college students. American Journal of Orthopsychiatry, 51(4), 719-723.

Weiner, S. (1998). The addiction of overeating: Self-help groups as treatment models. Journal of Clinical Psychology, 54, $163-167$.

Weiss, M. G. (1995). Eating disorders and disordered eating in different cultures. Psychiatric Clinics of North America, 18(3), 537-553.

Weiss, S. R., \& Ebert, M. H. (1983). Psychological and behavioral characteristics of normal-weight bulimics and normal-weight controls. Psychosomatic Medicine, 45(4), 293-303.

Westphal, V. K., \& Smith, J. E. (1996). Overeaters anonymous: Who goes and who succeeds? Eating Disorders, 4, $160-169$.

Williamson, D. F., Serdula, M. K., Anda, R. F., Levy, A., \& Byers, T. E. (1992). Weight loss attempts in adults: Goals, duration, and rate of weight loss. American Journal of Public Health, 82, 1251-1257.

Winner, L. F. (2000, September). The weight and the truth. Christianity Today, 4, 51-58.

Worldwide, D. N. (2000). DDB Needham Worldwide. DDB Needham Worldwide.

Xinaris, S., \& Boland, F. J. (1990). Disordered eating in relation to tobacco use, alcohol consumption, self-control, and sex-role ideology. International Journal of Eating Disorders, 9, 425-433.

Zinnbauer, B. J., Pargament, K. I., Cole, B., Rye, M. S., Butter, E. M., Belavich, T. G., et al. (1997). Religion and spirituality: Unfuzzying the fuzzy. Journal for the Scientific Study of Religion, 36(4), 549-564. 